\title{
Effect of Feeding Moringa oleifera Leaf Meal as Feed Additive on the Performance and Carcass Characteristics of Broiler Chicks
}

\author{
M. S. Meel ${ }^{*}$ and T. Sharma \\ Department of Animal Nutrition, College of Veterinary and Animal Science, Navania, \\ Vallabhnagar, Udaipur, Rajasthan University of Veterinary and Animal Sciences, Bikaner, \\ Rajasthan, India \\ *Corresponding author
}

\section{A B S T R A C T}

\section{Keywords}

Broilers, Moringa

oleifera leaf,

Performance,

Carcass quality

Article Info

Accepted:

04 December 2020

Available Online:

10 January 2021
A study was carried out to evaluate the effect of Moringa oleifera leaf meal (MOLM) as feed additive on the growth performance and carcass characteristics of broiler chicks. A total of 150 one day-old broiler chicks (Vencobb-400) were randomly assigned to five dietary treatments $\left(\mathrm{T}_{1}, \mathrm{~T}_{2}, \mathrm{~T}_{3}, \mathrm{~T}_{4}\right.$ and $\left.\mathrm{T}_{5}\right)$ containing MOLM at 0, 0.5, 1.0, 1.5 and 2.0\% inclusion levels respectively, in a complete randomized design experiment. The basal diet was formulated according to the BIS recommendations and used for the starter and finisher. The obtained results showed that dietary supplementation with different levels of moringa significantly improved the performance of broiler chicks and positively affected nutrient metabolizability, percentages of carcass yield, total edible parts and weights of giblets compared with their control counterparts. Results revealed that, effect of moringa leaf meal supplementation on average final body weight, average daily gain, average daily feed intake and feed conversion ratio were significant $(\mathrm{P}<0.01)$. Birds fed on 1.5\% MOLM diet showed heaviest body weight, with the best feed conversion ratio. It was concluded that supplementation of MOLM at $1.5 \%$ level of diet was effective in improving the performance of broiler chickens.

\section{Introduction}

The global population is steadily increasing and is projected to include approximately 9.6 billion peoples by 2050 . In addition, poultry production has increased during the last few years and in 2020 the OECD (FAO) was predicted to produce around 130 million tons of chicken meat to match the demand of a growing world population. Nowadays, the poultry industry is recognized as a fast growing component of the agricultural sector, which provides protein-rich food at affordable rates. However, this sector has drawn more attention towards environmental and food safety since animals including poultry gut microbes can be the source of bacterial pathogens such as Salmonella and Campylobacter which can disseminate to humans or act as a pool for antibiotic resistance and transmission and therefore may pose a serious threat to public health (Kumar 
et al., 2018). These gut microbes compete with the host for energy and protein. In both the proximal and distal gut, microbes produce toxic metabolites (e.g., amino acid catabolites) and catabolize bile acids, which may depress growth and decrease fat digestibility of the birds, respectively (Gaskins et al., 2002). Due to drug resistance problems associated with antibiotic use and increasing consumers demand for antibiotic residue-free products, most researchers are looking for a natural alternatives (herbal feed additives) to antibiotic growth promoters.

Moringa oleifera (drumstick) is one of the plants that can be used in the preparation of poultry feed. The plant in addition to being a good source of vitamins and amino acids, it has wide range of medicinal value including growth promotion and antimicrobial effect (Mbikay, 2012 and Moyo et al., 2011). Siddhuraju and Becker (2003) reported that moringa leaves have potential prebiotic effects and potentially antioxidant phytochemicals, such as chlorogenic acid and caffeic acid. Moringa oleifera leaf meal, widely available in many tropical countries, is also a good source of antioxidant compounds such as ascorbic acid, flavonoids, phenolics and carotenoids (Teixeira et al., 2014). Moringa oleifera leaves contained crude protein $27.51 \%$, crude fiber $19.25 \%$, crude fat $2.23 \%$, ash $7.13 \%$, moisture $76.53 \%$, carbohydrates $43.88 \%$ and calorific value $1296 \mathrm{~kJ} / 100 \mathrm{~g}$.

The calcium and iron levels were 20.09 and $28.29 \mathrm{mg} / 100 \mathrm{~g}$ (DM), respectively (Oduro et al., 2008). Additionally, Moringa oleifera leaves have high protein content $(20-35 \%$ of DM) with high levels of all the essential amino acids (Foidl and Paul, 2008).

Therefore, the present study was carried out to evaluate the effect of Moringa oleifera leaf meal (MOLM) as feed additive on the growth performance and carcass characteristics of broiler chicks.

\section{Materials and Methods}

One hundred and fifty, one-day old unsexed (Vencobb-400) broiler chicks were randomly distributed into 5 groups of 30 chicks. Each group was further subdivided into 3 replicates with 10 chicks per each. Five levels of Moringa oleifera leaf meal (MOLM) 0.0, 0.5, $1.0,1.5$ and $2 \%$ (treatments $\mathrm{T}_{1}, \mathrm{~T}_{2}, \mathrm{~T}_{3}, \mathrm{~T}_{4}$ and $\mathrm{T}_{5}$ ) were fed during the experimental period for 42 days duration. All the experimental diets were to meet the nutrient requirements of broiler chicks according to BIS (1992) which were procured from of Godrej Agrovet Limited. Good quality Moringa oleifera leaf meal (MOLM) powder was procured from Sinhal Herbs, Neemuch, M.P. The chemical compositions of broiler starter, broiler finisher and MOLM were analysed according to the standard methods of analysis (AOAC, 2016) which is shown in Table 1. The chemical composition of experimental feed offered to broiler chicks in different treatment groups during feeding trial is shown in Table 2. Feed and water were supplied ad - libitum, and uniform light was provided $24 \mathrm{hr}$ daily. The performance of broiler chicks was recorded weekly in terms of feed intake, live weight gain and feed conversion ratio. At the end of the experiment the chicks were weighed individually after overnight fasting (except water), then slaughtered by severing the jugular vein without stunning and 5 minutes bleeding time was allowed for each bird. The dressed weight was expressed as percentage of live weight. The giblets (heart, liver and gizzard) were cleaned and retained along with the carcass to record eviscerated weight and expressed as percentage of pre-slaughter weight.

Statistical analyses were made by analysis of variance (ANOVA) for a completely 
randomized design, according to (Snedecor and Cochran, 1989) and means were tested for significant differences as per Duncan's multiple range test (Duncan, 1955).

\section{Results and Discussion}

Performance of broiler chicks fed on different levels of Moringa oleifera leaf meal (MOLM) is shown in Table 3. Body weight gain, feed intake, feed conversion ratio (FCR) and performance index (PI) were improved significantly $\quad(\mathrm{P}<0.01) \quad$ with the supplementation of moringa leaf meal in the broiler's diet. The diet supplemented with $1.5 \%$ MOLM showed significantly heaviest body weight gain with better feed conversion ratio and performance index. The improvement in weight of birds fed on a moringa supplemented diet may be attributed to the high protein content of the diet, which was efficiently metabolized for growth. This result was in accordance with the finding of Tazi and Tibin (2014) and Ayo-Ajasa et al., (2016), who reported significantly higher weight gain of birds fed diets with MOLM as compared to the control. The total feed consumption was decreased significantly $(\mathrm{P}<0.01)$ with the increasing level of MOLM. This reduction could be due to reduced palatability of the diet (Kakengi et al., 2003). The results coincided with the finding of $\mathrm{Abu}$ et al., (2020) and Mikhail et al., (2020) who reported significant decrease in feed intake as the inclusion rate of MOLM in the broilers diet increased. The FCR and PI were significantly $(\mathrm{P}<0.01)$ improved of the birds fed on MOLM based diets as compared to control group. These results were similar to the findings of $\mathrm{Abu}$ et al., (2020) who reported that feed conversion ratio and performance index of birds were improved as level of MOLM increased in the diet of birds. Contrary to this, Aderinola et al., (2013) reported significant increase in the feed conversion ratio of the birds fed MOLM based diets than birds that are fed without MOLM. This improvement in body weight gain and feed conversion ratio may be attributed to rich content of nutrients in MOLM (Kakengi et al., 2003) and antimicrobial properties of Moringa (Fahey et al., 2001).

Table.1 Chemical composition of broiler starter, broiler finisher and MOLM (\%DM basis)

\begin{tabular}{|c|l|c|c|c|}
\hline S. No. & Chemical composition & Broiler starter & Broiler finisher & MOLM \\
\hline $\mathbf{1 .}$ & Dry matter & 91.20 & 91.51 & 94.32 \\
\hline $\mathbf{2 .}$ & Crude protein & 21.36 & 20.24 & 24.56 \\
\hline $\mathbf{3 .}$ & Ether extract & 4.13 & 4.56 & 7.10 \\
\hline $\mathbf{4 .}$ & Crude fibre & 3.70 & 3.70 & 7.82 \\
\hline $\mathbf{5 .}$ & Total ash & 6.75 & 6.70 & 9.20 \\
\hline $\mathbf{6 .}$ & Nitrogen free extract & 64.06 & 64.80 & 51.32 \\
\hline $\mathbf{7 .}$ & Acid insoluble ash & 1.25 & 1.35 & 0.51 \\
\hline $\mathbf{8 .}$ & NDF & 9.90 & 10.11 & 11.30 \\
\hline $\mathbf{9 .}$ & ADF & 3.33 & 3.53 & 8.39 \\
\hline $\mathbf{1 0 .}$ & Calcium & 1.16 & 0.88 & 1.58 \\
\hline $\mathbf{1 1 .}$ & Phosphorus & 1.18 & 0.93 & 0.30 \\
\hline $\mathbf{1 2 .}$ & ME (Kcal/kg of feed) & 2950 & 3100 & - \\
\hline $\mathbf{1 3 .}$ & E/P ratio & $138.11: 1$ & $153.16: 1$ & - \\
\hline
\end{tabular}


Table.2 The chemical composition of experimental feed offered during feeding trial to broiler chicks (\% DM basis)

\begin{tabular}{|l|c|c|c|c|c|}
\hline \multirow{2}{*}{ Parameters } & \multicolumn{5}{|c|}{ Treatment groups } \\
\cline { 2 - 6 } & $\mathbf{T}_{\mathbf{1}}$ & \multicolumn{5}{|c|}{$\mathbf{T}_{\mathbf{2}}$} & \multicolumn{2}{|c|}{$\mathbf{T}_{\mathbf{3}}$} & $\mathbf{T}_{\mathbf{4}}$ & $\mathbf{T}_{\mathbf{5}}$ \\
\hline DM & 91.20 & 91.23 & 91.21 & 91.20 & 91.20 \\
\hline CP & 21.36 & 21.38 & 21.40 & 21.42 & 21.44 \\
\hline EE & 4.13 & 4.17 & 4.21 & 4.25 & 4.29 \\
\hline CF & 3.70 & 3.73 & 3.76 & 3.79 & 3.82 \\
\hline TA & 6.75 & 6.75 & 6.77 & 6.79 & 6.79 \\
\hline AIA & 1.25 & 1.25 & 1.25 & 1.25 & 1.24 \\
\hline NDF & 9.90 & 9.93 & 9.95 & 9.98 & 9.99 \\
\hline ADF & 3.33 & 3.37 & 3.41 & 3.43 & 3.47 \\
\hline Ca & 1.16 & 1.16 & 1.16 & 1.17 & 1.18 \\
\hline P & 1.18 & 1.18 & 1.18 & 1.17 & 1.17 \\
\hline & & $\mathbf{B r o i l e r}$ & finisher & & \\
\hline DM & 91.51 & 91.52 & 91.52 & 91.50 & 91.53 \\
\hline CP & 20.24 & 20.26 & 20.28 & 20.30 & 20.32 \\
\hline EE & 4.56 & 4.61 & 4.65 & 4.69 & 4.74 \\
\hline CF & 3.70 & 3.74 & 3.76 & 3.79 & 3.82 \\
\hline TA & 6.70 & 6.70 & 6.72 & 6.72 & 6.73 \\
\hline AIA & 1.35 & 1.35 & 1.35 & 1.35 & 1.34 \\
\hline NDF & 10.11 & 10.13 & 10.15 & 10.18 & 10.19 \\
\hline ADF & 3.53 & 3.54 & 3.57 & 3.59 & 3.60 \\
\hline Ca & 0.88 & 0.88 & 0.88 & 0.89 & 0.90 \\
\hline P & 0.93 & 0.93 & 0.93 & 0.92 & 0.92 \\
\hline
\end{tabular}

Table.3 Performance of broiler chicks fed on different levels of Moringa oleifera leaf meal (MOLM)

\begin{tabular}{|c|c|c|c|c|c|c|}
\hline \multirow[t]{2}{*}{ Parameters } & \multicolumn{5}{|c|}{ Treatment groups } & \multirow[t]{2}{*}{ SEM } \\
\hline & $T_{1}$ & $\mathbf{T}_{2}$ & $\mathbf{T}_{3}$ & $\mathbf{T}_{4}$ & $\mathbf{T}_{5}$ & \\
\hline $\begin{array}{l}\text { Initial live weight } \\
\text { (g/chick) }\end{array}$ & 42.20 & 42.51 & 42.39 & 42.26 & 42.51 & 0.056 \\
\hline $\begin{array}{l}\text { Final live weight } \\
\text { (g/chick) }\end{array}$ & $1878.20^{\mathrm{a}}$ & $2035.33^{b}$ & $2108.26^{c}$ & $2170.97^{d}$ & $2089.94^{c}$ & 22.992 \\
\hline $\begin{array}{l}\text { Body weight gain } \\
\text { (g/chick) }\end{array}$ & $1836.00^{\mathrm{a}}$ & $1992.82^{b}$ & $2065.87^{c}$ & $2128.70^{d}$ & $2047.43^{c}$ & 22.995 \\
\hline $\begin{array}{l}\text { Total feed intake } \\
\text { (g/chick) }\end{array}$ & $3923.20^{c}$ & $3770.25^{\mathrm{ab}}$ & $3785.18^{\mathrm{ab}}$ & $3746.00^{\mathrm{ab}}$ & $3704.89^{\mathrm{a}}$ & 17.282 \\
\hline $\begin{array}{l}\text { Feed conversion } \\
\text { ratio }\end{array}$ & $2.03^{d}$ & $1.84^{\mathrm{c}}$ & $1.75^{\mathrm{b}}$ & $1.72^{\mathrm{ab}}$ & $1.75^{\mathrm{b}}$ & 0.018 \\
\hline Performance index & $906.14^{\mathrm{a}}$ & $1081.83^{b}$ & $1180.16^{\mathrm{c}}$ & $1241.15^{\mathrm{d}}$ & $1172.79^{c}$ & 22.887 \\
\hline
\end{tabular}


Table.4 Effect of Moringa oleifera leaf meal on carcass evaluation parameters (\% of live weight) and organs weight (g)

\begin{tabular}{|c|c|c|c|c|c|c|}
\hline \multirow{2}{*}{ Parameters } & \multicolumn{5}{|c|}{ Treatment groups } & \multirow{2}{*}{ SEM } \\
\cline { 2 - 6 } & $\mathbf{T}_{\mathbf{1}}$ & $\mathbf{T}_{\mathbf{2}}$ & $\mathbf{T}_{\mathbf{3}}$ & $\mathbf{T}_{\mathbf{4}}$ & $\mathbf{T}_{\mathbf{5}}$ & \\
\hline Dressing yield (\%) & $72.45^{\mathrm{a}}$ & $73.50^{\mathrm{b}}$ & $73.89^{\mathrm{bc}}$ & $74.15^{\mathrm{bcde}}$ & $73.95^{\mathrm{bcd}}$ & $\mathbf{0 . 1 6 4}$ \\
\hline Eviscerated yield (\%) & $67.24^{\mathrm{a}}$ & $68.43^{\mathrm{b}}$ & $68.79^{\mathrm{bc}}$ & $69.00^{\mathrm{bcde}}$ & $68.95^{\mathrm{bcd}}$ & $\mathbf{0 . 1 6 9}$ \\
\hline Liver (g) & $53.14^{\mathrm{a}}$ & $58.56^{\mathrm{b}}$ & $61.78^{\mathrm{c}}$ & $67.82^{\mathrm{d}}$ & $67.80^{\mathrm{d}}$ & $\mathbf{1 . 0 2 4}$ \\
\hline Heart (g) & $10.23^{\mathrm{a}}$ & $10.75^{\mathrm{b}}$ & $11.24^{\mathrm{d}}$ & $11.10^{\mathrm{c}}$ & $11.46^{\mathrm{e}}$ & $\mathbf{0 . 1 0 6}$ \\
\hline Gizzard (g) & $34.45^{\mathrm{a}}$ & $34.68^{\mathrm{b}}$ & $35.13^{\mathrm{c}}$ & $35.67^{\mathrm{d}}$ & $35.84^{\mathrm{e}}$ & $\mathbf{0 . 1 1 7}$ \\
\hline Giblet (g) & $97.82^{\mathrm{a}}$ & $103.99^{\mathrm{b}}$ & $108.15^{\mathrm{c}}$ & $114.59^{\mathrm{d}}$ & $115.10^{\mathrm{e}}$ & $\mathbf{1 . 2 3 6}$ \\
\hline
\end{tabular}

Effect of Moringa oleifera leaf meal on carcass evaluation parameters and organs weight is shown in Table 4. Broiler chicks fed on diets supplemented with MOLM showed highly significant $(\mathrm{P}<0.01)$ effect on dressing yield and eviscerated yield. Highest dressing and eviscerated percentage were recorded to be $74.15 \%$ and $69.00 \%$ respectively in $\mathrm{T}_{4}$ group containing $1.5 \%$ MOLM and the lowest values were found in control group. These findings were in accordance to AyoAjasa et al., (2016), Tijani et al., (2016) and Safa (2014) who reported that the addition of MOLM in the diets significantly $(\mathrm{P}<0.05)$ increased the dressing and eviscerated weight percentage. However, Tesfaye et al., (2013) reported that eviscerated yield was not affected by treatment $(\mathrm{P}>0.05)$ of MOLM in broiler. Onunkwo and George (2015) reported that there was no significant difference in dressing percentage in all the dietary treatments of MOLM fed groups.

As shown in Table 4 there was highly significant $(\mathrm{P}<0.01)$ effect on weight of liver, heart, gizzard and giblet due to supplementation of Moringa oleifera leaf meal as feed additive in broilers ration. Highest weight of heart, gizzard and giblet was recorded to be $11.46,35.84$ and $115.10 \mathrm{~g}$ respectively in $\mathrm{T}_{5}$ group containing $2.0 \%$ MOLM and highest liver weight was recorded to be $67.82 \mathrm{~g}$ in $1.5 \%$ MOLM supplemented group. In congruence to results of present study, Abousekken (2015) reported that the significantly $(\mathrm{P}<0.05)$ higher values of organ weight $(\%)$ of gizzard, liver and heart of birds fed moringa leaves extracts. Aderinola et al., (2013) observed significant effect of feeding MOLM on liver and gizzard weight. Voemesse et al., (2018) observed that gizzard weight was significantly increased $(\mathrm{P}<0.05)$ in chickens fed 0,1 and 3\% MOLM as compared to control. Contrary to this, Mikhail et al., (2020) found non-significant effect on giblet, liver and gizzard weight of broilers fed MOLM at 0, 2.5, 5, and 7.5\% level.

In conclusion these results suggested that Moringa oleifera leaf meal could be used as a feed additive for broilers to improve growth performance without adverse effects, with addition of $1.5 \%$ in the diets.

\section{Acknowledgement}

The authors are thankful to the RAJUVAS, Bikaner and Dean, College of Veterinary and Animal Science, Navania, Vallabhnagar, Udaipur for providing necessary facilities and financial support to conduct this research.

\section{References}

Abousekken, M.S.M. 2015. Performance, Immune Response and carcass quality of broilers fed low protein diets contained either Moringa oleifera 
leaves meal or its extract. Journal of American Science, 11(6): 153-164.

Abu, H.S., Ibrahim, S., Eid, Y. and Hassan, A. 2020. Effect of dietary Moringa oleifera leaves on the performance, ileal microbiota and antioxidative status of broiler chickens. Journal of Animal Physiology and Animal Nutrition. 104. 10.1111/jpn.13281.

Aderinola O.A, Rafiu T.A, Akinwumi A.O, Alabi T.A. and Adeagbo O.A. 2013. Utilization of Moringa oleifera leaf as feed supplement in broiler diet. Inter Jour of Food, Agri and Vety Sci. 3(3): 94-102.

AOAC. 2016. Official method of analysis, $20^{\text {th }}$ edition, Association of Official Analytical Chemists, Washington, D.C.

Ayo-Ajasa, O.Y., Abiona, J.A., Fafiolu, A.O., Egbeyale, L.T., Njoku, C.P., Omotay, I.G., Odeyemi, A.Y. and Abel, F.A.S. 2016. Performance characteristics of broilers fed graded levels of Moringa oleifera leaf meal. Malaysian Journal of Animal Science, 19(1): 23-31.

BIS. 1992. Bureau of Indian Standards, Poultry Feeds Specification. $\quad\left(4^{\text {th }}\right.$ Revision), Manak Bhavan, 9 Bahadur Shah Zafar Marg, New Delhi-11.

Duncan, D.B. 1955. Multiple range and multiple F test. Biometrics, 11: 1-42.

Fahey, J.W., Zalcmann, A.T. and Talalay, P. 2001. The chemical diversity and distribution of glucosinolates and isothiocyanates among plants. Phytochemistry, 56:5-51.

Foidl, N. and Paul, R. 2008. Moringa oleifera. In: The Encyclopedia of Fruit and Nutrition, ABI, Oxfordshire, UK., 509512.

Gaskins, H.R., Collier, C.T. and Anderson, D.B. 2002. Antibiotics as growth promotants: Mode of action. Anim Biotechnol. 13:29-42.

Kakengi, A.M.V., Shem, M.N., Sarwatt, S.V. and Fujihara, T. 2003. Can Moringa oleifera be used as a protein supplement to ruminants? AsianAustralasian Journal of Animal Sciences, 18(1): 42-47.

Kumar, S., Chen, C., Indugu, N., Werlang, G.O., Singh, M., Kim, W.K. and Thippareddi, H. 2018. Effect of antibiotic withdrawal in feed on chicken gut microbial dynamics, immunity, growth performance and prevalence of food borne pathogens. PloS ONE (2018) 13:e0192450. 10.1371/journal.pone.0192450.

Mbikay, M. 2012. Therapeutic potential of Moringa oleifera leaves in chronic hyperglycemia and dyslipidemia. Pharmacol, 3: 1-2.

Mikhail, W.Z.A., El-Samee, M.O.A., El-Afifi, T.M. and Mohammed, A.R. 2020. Effect of feeding Moringa oleifera leaf meal with or without enzyme on the performance and carcass characteristics of broiler chicks. Plant Archives, 20(1): 3381-3388.

Moyo, B., Masika, P.J., Hugo, A. and Muchenje, V. 2011. Nutritional characterization of Moringa (Moringa oleifera Lam) leaves. Afr. J. Biotechol, 10(60): 2925-2933.

Oduro, I., Ellis, W.O. and Owusu, D. 2008. Nutritional potential of two leafy vegetables: Moringa oleifera and Ipomoea batatas leaves. Sci. Res. Essay, 3: 57-60.

Onunkwo, D.N. and George, O.S. 2015. Effects of Moringa oleifera leaf meal on the growth performance and carcass characteristics of broiler birds. Journal of agriculture and Veterinary Science, 8(3): 63-66.

Safa, M.A.E. 2014. Effect of feeding different levels of Moringa oleifera leaf meal on the performance and carcass quality of broiler chicks. International Journal of Science and Research, 3(5): 147-151. 
Siddhuraju, P. and Becker, K. 2003. Antioxidant properties of various solvent extracts of total phenolic constituents from three different agroclimatic origins of drumstick tree (Moringa oleifera Lam.) leaves. $J$ of Agri. and Food Chem. 51(8): 21442155.

Snedecor, G.W. and Cochran, W.G. 1989. Statistical methods. Oxford and IBH Publishing Company, New Delhi.

Tazi, S.M.E. and Tibin, I. 2014. Performance and blood chemistry as affected by inclusion of Moringa oleifera leaf meal in broiler chicks diet. Journal of Veterinary Medicine and Animal Production, 5 (2): 58-65.

Teixeira, E.M.B., Carvalho, M.R.B., Neves, V.A., Silva, M.A. and Arantes-Pereira, L. 2014. Chemical characteristics and fractionation of proteins from Moringa oleifera Lam Leaves. Food Chem.
147:51-54.

Tesfaye E., Getachew A., Mengistu U. and Tadelle D. 2013. Moringa oleifera leaf meal as an alternative protein feed ingredient in broiler ration. International Journal of Poultry Science, 12(5): 289-297.

Tijani, L.A., Akanji, A.M., Agbalaya, K. and Onigemo, M. 2016. Effects of Moringa oleifera leaf meal on performance, nutrient digestibility and carcass quality of broiler chickens. Applied Tropical Agriculture, 21(1): 46-53.

Voemesse, K., Teteh, A., Nideou, D., Nnanle, O., Gbeassor, M., Decuypere, E. and Tona, K. 2018. Effect of Moringa oleifera leaf meal on growth performance and blood parameters of egg type chicken during juvenile growth. Int. J. Poult. Sci., 17: 154-159.

\section{How to cite this article:}

Meel, M. S. and Sharma, T. 2021. Effect of Feeding Moringa oleifera Leaf Meal as Feed Additive on the Performance and Carcass Characteristics of Broiler Chicks. Int.J.Curr.Microbiol.App.Sci. 10(01): 40-46. doi: https://doi.org/10.20546/ijcmas.2021.1001.006 